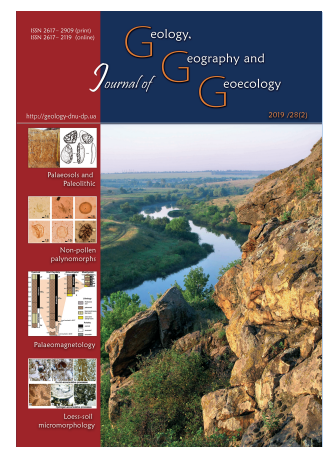

O.M. Adamenko
Journal of Geology. Geography and Geoecology

Journal home page: geology-dnu-dp.ua
ISSN 2617-2909 (print)

ISSN 2617-2119 (online)

Journ.Geol.Geograph.

Geology,

28(2), 213-220.

doi: $10.15421 / 111922$

\title{
The Upper Pleistocene stratigraphy of the Starunya site as a "bridge" between the stratigraphical frameworks of Western Europe and the plain area of Ukraine
}

\author{
O.M. Adamenko
}

Ivano-Frankivsk National Technical University of Oil and Gas, Ivano-Frankivsk, Ukraine, e-mail: katolrad22@gmail.com

Received: 23.01.2019

Received in revised form: 04.02.2019

Accepted: 28.04.2019

\begin{abstract}
The first discoveries of mummified carcasses of the woolly rhinoceros, mammoth, horse, roe deer and other animals were made at a depth of $12 \mathrm{~m}$ in the course of mining work at an ozokerite mine near the village of the Starunia. In 1929 an expedition of the Academy of Arts and Sciences from Krakow, when investigating the mine at a depth of
\end{abstract} $17 \mathrm{~m}$, found the remains of 3 more woolly rhinoceroses. There were also numerous bones of small vertebrates (rodents), artichokes, numerous insects, beetles, parasitic worms, fleas, butterflies, spiders, snails, vascular plants, seeds and branches of dwarf birch, alder, and other representatives of tundra flora. In March 1977, after the earthquake in the Vrancha Mountains (Romania), the first and still the only mud volcano in the Carpathians, which added an entirely new " note " to the Starunia paleontological location, arose on the ozokerite deposit. In the 1970s-80s several dozen remains of ancient man from the late Paleolithic, Mesolithic and Neolithic periods were discovered. In 2004-2009, two Ukrainian-Polish expeditions were organized. The results of both expeditions were published in 2005 in the book «Polish and Ukrainian Geological Studies (2004-2005) at Starunia - the area of discoveries of Woolly Rhinoceros» and the scientific collection «Interdisciplinary Studies (2006-2009) at Starunia (Carpathian Region, Ukraine). The main achievements are set forth in 17 articles and relate to the geological environment, geomorphology, lithology, stratigraphy and paleography of the Holocene deposits, their palynological and paleobotanical characteristics, chronostratigraphy and environmental changes during the period of the late Pleistocene and Holocene, and also research by methods of electric probe, gravity and microgravity survey, geochemical analysis, microbiological characteristics and bitumen of Quaternary deposits. An important result was the discovery of the most productive area where the remains of giant mammals and even Pleistocene Cro-Magnon could still be found at depths. All the numerous interdisciplinary research of Polish and Ukrainian scientists confirms the uniqueness of Starunia on a global scale, requiring the preservation and further study of the paleontological finds and of the only mud volcano in the Carpathians. Such findings can only be made by organizing the Starunia International Ecological and Tourist Center «Geopark Ice Age».

Keywords: Upper Pleistocene, woolly rhinoceros, mammoth, tundra, natural-man-made geosystems, paleoclimate.

\section{Схема стратиграфії верхнього плейстоцену Старуні як «місток» між аналогічними схе- мами Західної Європи та рівнинної України}

\section{О. М. Адаменко}

Івано-Франківський національний технічний університет нафти і газу, Україна, Івано-Франківськ, e-mail: katolrad22@gmail.com

Анотація. Перші знахідки муміфікованих туш волосатого носорога, мамонта, коня, козулі та інших тварин здійснювалися на глибині 12 м при проходженні гірничіх виробок для видобутку озокериту біля села Сатруня. У 1929 році експедиція Академії мистецтв та наук із Кракова, під час проходження шахти на глибині 17 м, виявила залишки ще 3 волохатих носорогів. Були також численні кістки дрібних хребетних (гризунів), артишоки, численні комахи, жуки, паразитичні хробаки, блощиці, метелики, павуки, слимаки, судинні рослини, насіння та гілки карликової берези, вільхи та інших представників тундрової флори. У березні 1977 року, після землетрусу в горах Вранча (Румунія), на озокеритовому родовищі виник перший і до цих пір унікальний грязьовий вулкан в Карпатах, який надав старунському палеонтологічному місцезнаходженню нове «звучання». У 70-80-х роках XX століття було виявлено декілька десятків стоянок стародавньої людини пізнього палеоліту, мезоліту і неоліту. 
У 2004-2009 роках було організовано дві українсько-польські експедиції. Результати обох експедицій були опубліковані у 2005 році в книзі «Польські та українські геологічні дослідження (2004-2005) у Старуні - області відкритя шерстистого носорога» та науковому збірнику «Міждисциплінарні дослідження (2006-2009) у «Старунії» (Карпати). Основні досягнення наведені в 17 статтях і стосуються геологічного середовища, геоморфології, літології, стратиграфії та палеографії голоценових відкладів, їх палінологічної та палеоботанічної характеристик, хроностратіграфії та зміни навколишнього середовища впродовж пізнього плейстоцену та голоцену, а також стосуються досліджень методами електричного зондуваня, граві- та магніторозвідки, геохімічних аналізів, мікробіологічних характеристик та бітумів четвертинних відкладів. Результатом цього було відкриття найбільш сприятливого району, де на глибині все ще можна виявити залишки гігантських ссавців і навіть кроманьонців плейстоцену. Усі численні міждисциплінарні дослідження польських і українських вчених підтверджують унікальність Старуні на глобальному рівні. що вимагає збереження і подальшого вивчення палеонтологічних знахідок і єдиного грязьового вулкана в Карпатах. Такі висновки можуть бути зроблені лише шляхом організації міжнародного еколого-туристичного центру «Геопарк Льодовиковий період».

Ключові слова: верхній плейстоцен, волохатий носоріг, мамонт, тундра, природно-антропогенні геосистеми, палеоклімати.

Relevance of the topic. The ecological state of the environment in the western region of Ukraine has considerably deteriorated over the last decade. It is caused by excessive recreational loading, pollution of water objects with domestic sewage, increasing emissions of vehicles into the air, uncontrolled felling of the forests, the impact of technogenically hazardous objects: Burshtinska TPP, Kalush salt mines, the Dombrovsky quarry and its tailings, objects of oil and gas extraction and petrochemical processing, unauthorized extraction of sand gravel-pebble deposits from river channels, active development of landslides, sulphurization, karst and erosion processes. The construction of a hydroelectric power station on the mountain rivers and the Dniester river, which involves the construction of a dam and a reservoir, water pipe lines along the channels of mountain rivers, can be a major new environmental threat. The catastrophic floods on the Dniester, Prut, Siret and Tisza rivers, which have become more frequent in recent years $(2002,2008,2018)$, are associated with a special threat to natural geosystems, economy, transport infrastructure and population, which is associated with global warming and increasing technogenic load on geosystems. The western region of Ukraine is located in the zone of developed atmospheric storm activity and, accordingly, in the area of increased risk of occurrence of waterborne disasters occurring on various scales, including catastrophic, flooding and waterlogging of territories, destruction of engineering infrastructures and disruption of communications with devastating consequences.

Therefore, it is important to map natural and human structures based on maps of Quaternary deposits, geomorphology, landscapes, which are based on a detailed stratigraphic dismemberment of the Pleistocene and Holocene supporting sections. One of such sections is Starunia - the paleontological location of the late Pleistocene fauna of wooly rhinos and mammoths in Bogorodchansk district of Ivano-
Frankivsk region, $18 \mathrm{~km}$ from the city of IvanoFrankivsk.

From the history of research. The first finds at this site of the wooly rhinoceros, mammoth, horse, roe deer, and other animals of the Pleistocene's socalled mammoth fauna were made in October 1907 at a depth of $12 \mathrm{~m}$ during the excavation of a shaft for the extraction of ozokerite near the village of Starunia. Scientists from Krakow and Lviv duly appreciated these unique discoveries and published a number of articles and a monograph in 1914 (Bayger, 1914; Lomnicki, 1908).

In 1929, an expedition of the Academy of Arts and Sciences from Krakow while digging a special research shaft found three more carcasses of woolly rhinoceros embalmed in bitumen and salt at a depth of $17 \mathrm{~m}$. There were also numerous rodent bones, mollusc shells, numerous insects, beetles, parasitic worms, fleas, butterflies, spiders, snails, vascular plants, dwarf birch seeds and branches, alder and other representatives of tundra flora (Kotarba, 2005). Comprehensive study of these finds and the corresponding publication were interrupted by the Second World War.

In the postwar years, ozokerite deposits in the villages of Starunia and Dzvinyach were explored, active exploration for oil was conducted, but its deposits in the dome of the Starunia fold proved not to be industrial.

In March 1977, after the earthquake in the Vrancha Mountains (Romania), on the ozokerite deposit of Starunia, the first mud volcano in the Carpathians arose, adding to the Starunia paleontological location a new «sound». Professors of the Ivano-Frankivsk Institute of Oil and Gas, N. Kh. Bilous and V. M. Klyarovsky, who studied the manifestations of mud volcanism in Starunia during 1977-1988 (Belous, Kliarovskyi, 1987), registered this 60 hectare site at as a natural geological monument of national value. At the same time, the 
study of Starunia drew the attention of geologists of the Department of General Geology of the Institute of Oil and Gas, O. Adamenko, O. R. Stelmakh, G. D. Stelmakhovich, N. M. Shevchuk, V. V. Kolencko (Adamenko, Kryzhanivskyi and Vekeryk, 2005; Adamenko, 2007; Adamenko et al, 2017; Adamenko O.M., Karpash O.M., Zorin D.O., Kotarba I.V., Mosiuk I.I., Kovbaniuk M.I., Adamenko O.M. 2007; Adamenko O.M., Kryzhanivskyi Ye.I., V.I. Vekeryk. 2005).

They were joined by paleontologists of the Natural History Museum of the National Academy of Sciences of Ukraine from Lviv, D. M. Drigant and others (Kotarba, 2005), as well as archaeologists of the Institute of Ukrainian Studies named after. I. Krepeyakevych of the National Academy of Sciences from Lviv, L.G.Matskevy and Ivano-Frankivsk Pedagogical Institute named after V. Stefanyk, B. A. Vasilenko and I. T. Kochkin (Adamenko, Kryzhanivskyi and Vekeryk, 2005; Lomnicki, 1908). In the vicinity of Starunia, several dozen remains of ancient man from the late Paleolithic, Mesolithic and Neolithic periods were discovered. It is worth mentioning that in 1914 Professor M. Lomnitsky (Bayger, 1914) wrote about a round hole in the skull of a rhinoceros, along with which a fragment of a wooden spear with a sharpened end was found. That shows that primitive hunters - Cro-Magnon lived alongside the woolly rhinoceros.

In 1988-1989 the Institute of Oil and Gas (O. M. Adamenko, O. R. Stelmakh, L. M. Mikhals'k, I. R. Mihailiuk) began research on Starunia financed by the Ministry of Education and Science of Ukraine. The detailed (1: 10,000) topographical (R.G. Pylypiuk) and radiometric (V.P. Stepaniuk) monitoring of the monument were also performed (Adamenko, Kryzhanivskyi and Vekeryk, 2005).

In 2004 two Polish-Ukraininan expeditions explored the area, their results were published in two monographs by M. Kotarba (Kotarba, 2005; Kotarba, 2009).

Materials and methods. In 2006-2009, it was possible to arrange drilling of 33 core wells with $100 \%$ core output for detailed study of sections II and I of the above-floodplain terraces and the re-enclosed valley of the River Lukavets Veliky buried beneath them. Geological and geomorphological, geophysical, geochemical studies with the use of modern technology continued. Several dozen radiocarbon dates from 44 to 11 thousand years have been received. Isotopic determination of carbon was performed to understand its origin from - taken from the depths of the oil deposit or from the decomposition of bioorganic plants and animals of the Pleistocene. Dozens of detailed spore-pollen charts, paleocarpological and malacofaunistic definitions have been obtained. The structure of deposits was detailed with the help of microgravity, electrostatic, microbiological methods. It is determined that the Pleistocene incision covers the period from the Eemian interglacial to the last phase of the Würm glaciation. The section of Holocene deposits is also studied in detail. But the most important result was the discovery of the most productive area, where the remains of Pleistocene mammals could still be found, and possibly their hunters - our ancestors Cro-Magnon, were found at depths from 4.5 to $8 \mathrm{~m}$ in paleoswamp sediments with a capacity of $2 \mathrm{~m}$ of bituminous black mud and salt

In 2016-2018 geologists and ecologists of the University of Oil and Gas, V.G. Omelchenko, T. Kalin, D.M. Vinnichuk, T.Yu. Fedorchak, V.P. Javorsky performed radiometric and snow-gauge measurements at Starunia, They evaluated the soil cover by selecting 133 samples and analyzing them for the content of heavy metals $\mathrm{Cd}, \mathrm{Pb}, \mathrm{Cu}, \mathrm{Zn}$ and petroleum products, and determined the surface water quality of the Lukavets Veliky and Rinne streams.

Presenting the main material. The Starunia paleontological location is located within the limits of the historic nature monument of Starunia with an area of 60 hectares (Belous \& Kliarovskyi, 1987) or on the Starunia geodynamic landfill (Adamenko et al., 2017). In geological-tectonic terms, this is the Boryslav-Pokutsky zone of the Precarpathian regional (advanced) deflection of the Carpathian oil and gas province (Kotarba, 2009).

The Quaternary part of the geological section is represented (from the top down) by the Miocene molasse of the Vorotischenskaya suite, often saline, criss crossed by ozokerite veins. Below is a flysch - a varied rhythmic alternation of sandstones, siltstones, argillites from the Upper Cretaceous to the lower Miocene (Stryi-Menilite suites). The BoryslavPokutsk (Inner) zone of the Precarpathian Bend is a complex of covers, chunks, and scales piled one upon another in a north-easterly direction. The zone from the southwest borders the Skybavy Carpathians, and in the north-east it borders Sambirskaya, and then further it borders the Bilche-Volytsky (External) bend zone. And further east-north-east extends the East European plain.

Oil and gas is associated with several horizons of the Menilite suite (Oligocene-lower Miocene) and middle Eocene. In the immediate vicinity to Starunia, there are several oil and gas condensate fields - Gvizdetsk, South-Gvizdetsk, Vysotsky, 
Monastyrchanske, Pnivske, Pasichniansk, BiitkovBabchinsk. To the south-east of Starunia there is another deposit of ozokerite - Dzvinske, and further to the north - the Starunia deposit of natural salts.

The Quaternary part of the geological section has been studied only in recent years, after well drilling and core research (Fig. 1) (Kotarba, 2009; Sokolowski T. \& Stachowicz-Rybka, 2009). The geological section (Fig.2) was made by the author, according to the results of drilling, using space images and aerial photography from a drone.

The south-western part of the study area is the slope of the watershed, covered with Eolian-deluvial, so-called covered with loess-like loams and clay of pale-brown, yellow-grey and brown colour edp, $Q^{2-3}$. The zones contain numerous lenses of sand, gravel, rough debris of native rocks. There is a similar slope is to the east. Between the slopes is the valley of the Veliki Lukavets with II and I above- floodplain terraces, the alluvium of which is blocked by deluvial-proluvialtechnogenic clay-salt deposits of mud-oil-salt streams $d p t Q_{4}{ }^{3}$ and man-made debris-clay deposits of mining waste dumps $t Q_{4}^{3}$ (Fig. 2).

Alluvium II $a Q_{3}{ }^{I-2}$ and I $a Q_{3}^{3-4}$ of the terraces are represented by stream deposited pebbles, with gravel and sand at the bottom of the sections, and the greater part of the preposterior part are lake-marsh facies dark-grey, often bituminous, peaty namulas $\operatorname{lh} Q_{3}^{2}$ and $l h Q_{3}^{4}$. Under the terraces is the reburied, buried ancient valley $a l Q_{3}{ }^{l} e$. In the lower sections of the I terrace the remains of four rhinos and one mammoth were found.

The section of the quarter is finished with alluvial gravel and pebbles, loam and silt of high $a Q_{4}{ }^{l}$, middle $a l Q_{4}{ }^{2}$ and lower $a Q_{4}^{3}$ of the floodplain terraces. The youngest Holocene formations include deposits of a mud volcano $v Q_{4}^{3}$ and oil emissions $p t Q_{4}^{3}$ from wells and «volcanoes».

The age of the Quaternary deposits is determined by radiocarbon dating of the mammals and molluscs, paleocarpological and palynological (spore-pollen) complexes and archaeological cultures.

Radiocarbon dating of the cores of the section of the 16th wells and $2 \mathrm{~d}$ outcrop showed that the minimum age of the peat, peat mud, biogenic and clay mud fluctuates within the preboreal, that is, the late pleniglacial (28-13 thousand years ago). There are more ancient dates (34-48 thousand yerars ago.), which refer to the middle pleniglacial. The Holocene deposits are dated from 230-325 to 4,505-5,490 and 11,110-11,430 years ago. T.T. Kis, K. Rosanski, T. Gloslar, R. Stachowicz-Rybka (Kuc, T., Rozahski K., Goslar T., Stachowicz - Rybka R., 2009), who performed radiocarbon studies, believe that the age given by $\mathrm{C} 14$ is «deformed», because the samples are saturated with bitumen, oil and salt. It is recommended to continue to search for unchanged samples for radiocarbon dating.

Archaeological research. In 1976-1982, the Carpathian archaeological expedition of the Institute of Social Sciences (now the I. Krepiakevych Institute of Ukrainian Studies, NASU) (Matskevyj L.G., 2005) carried out comprehensive research in the vicinity of the village Starunia. As a result, near the paleontological location, 12 partially 2-3 spherical stands were discovered, in which at least 17 settlements of ancient man from the Paleolithic to the Middle Ages were traced. Thus, for millennia the territory was favourable for the settlement of our ancestors who hunted large animals.

This reveals great possibilities in Starunia for discovering the remains of people from the CroMagnon Era to later epochs. Such finds can be found both in settlements, and in deposits of ancient swamps. Stationary excavations have been carried out only at settlements of the Mesolithic and Neolithic periods in an area of $1649 \mathrm{~m}^{2}$. More than 5 thousand artifacts and faunal remains (Starunia and culture of VorotsivStarunia) have been found.

It is advisable to conduct excavations according to L.G. Matskevyj (Matskevyj, 2005), in the settlements of Starunia IV and XI, located nearer to the findings of woolly rhinoceros and mammoth.

Malacofauna, paleocarpological and palynological complexes have shown that in the late Pleistocene, Starunia is characterized by multiple alternation of periods of cooling with tundra flora and warming periods, which allowed us to offer a comparison (correlation) of the stratigraphic schemes of the upper Pleistocene of Starunia with similar schemes in Western Europe and lowland Ukraine (Table 1) .

On the basis of the obtained data, the author carried out paleoclimatic reconstruction, which should be characterized as from the post-Miocene age, the period of formation of the valley of the Dniester River and its tributaries , $1^{\text {st }}$ order - the Bystrytsia River, $2^{\text {nd }}$ - the Bystrytsy Solotvynsky and $3^{\mathrm{d}}-$ the Veliki Lukovets, in which Starunia is located.

Consequently, at the end of the Miocene, the island of the Carpathian bend rose from the Thetis Ocean and its continental development began. In the Pliocene, the north-eastern macro-slope of the Carpathians was dismembered by many parallel river valleys, which carried from the mountains a coarsedeep alluvium, forming along the mountain range 
T. SOKOEOWSKI ET AL.

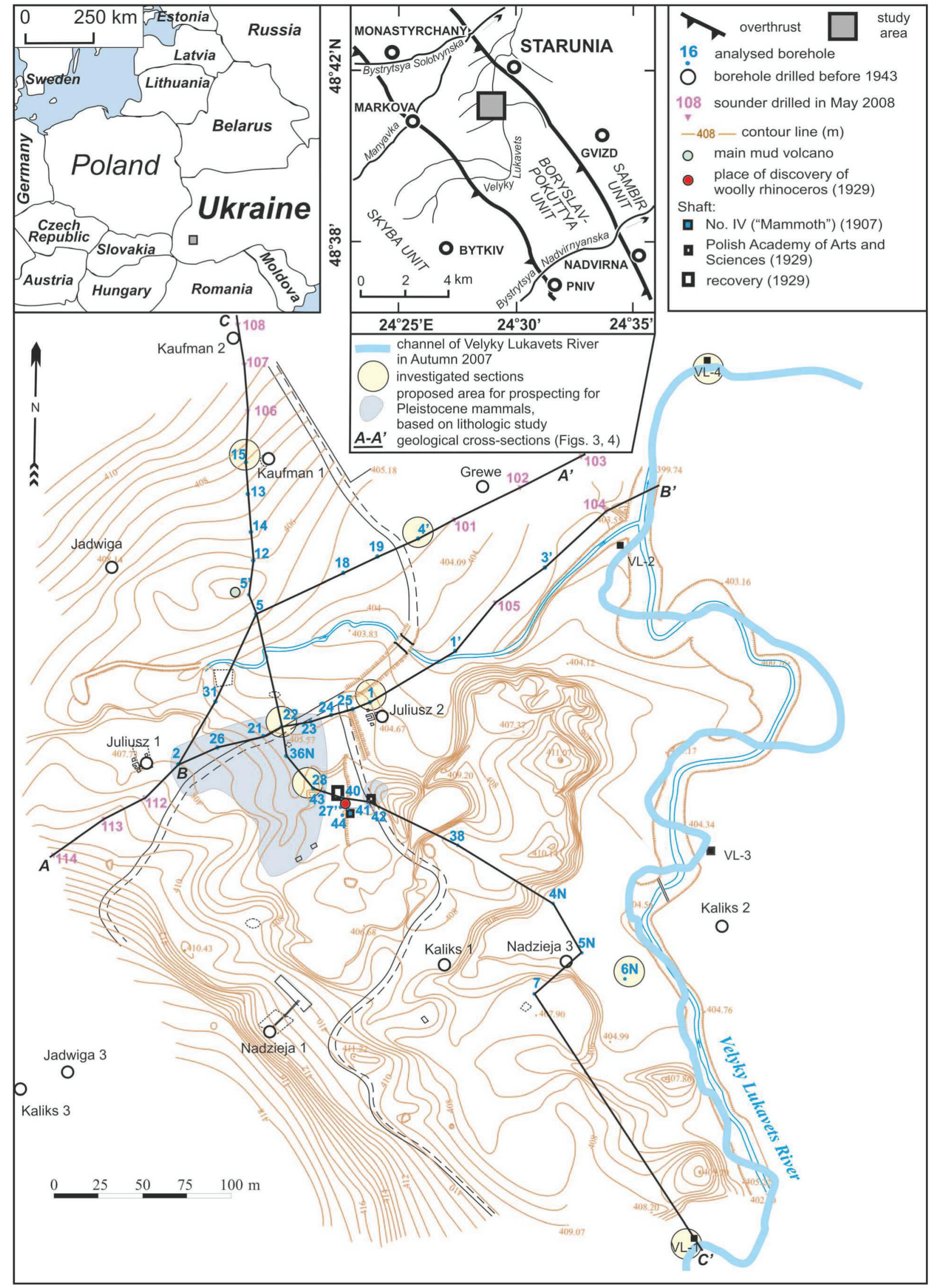

Fig. 1. Schematic map of the location of geological sections [15] 


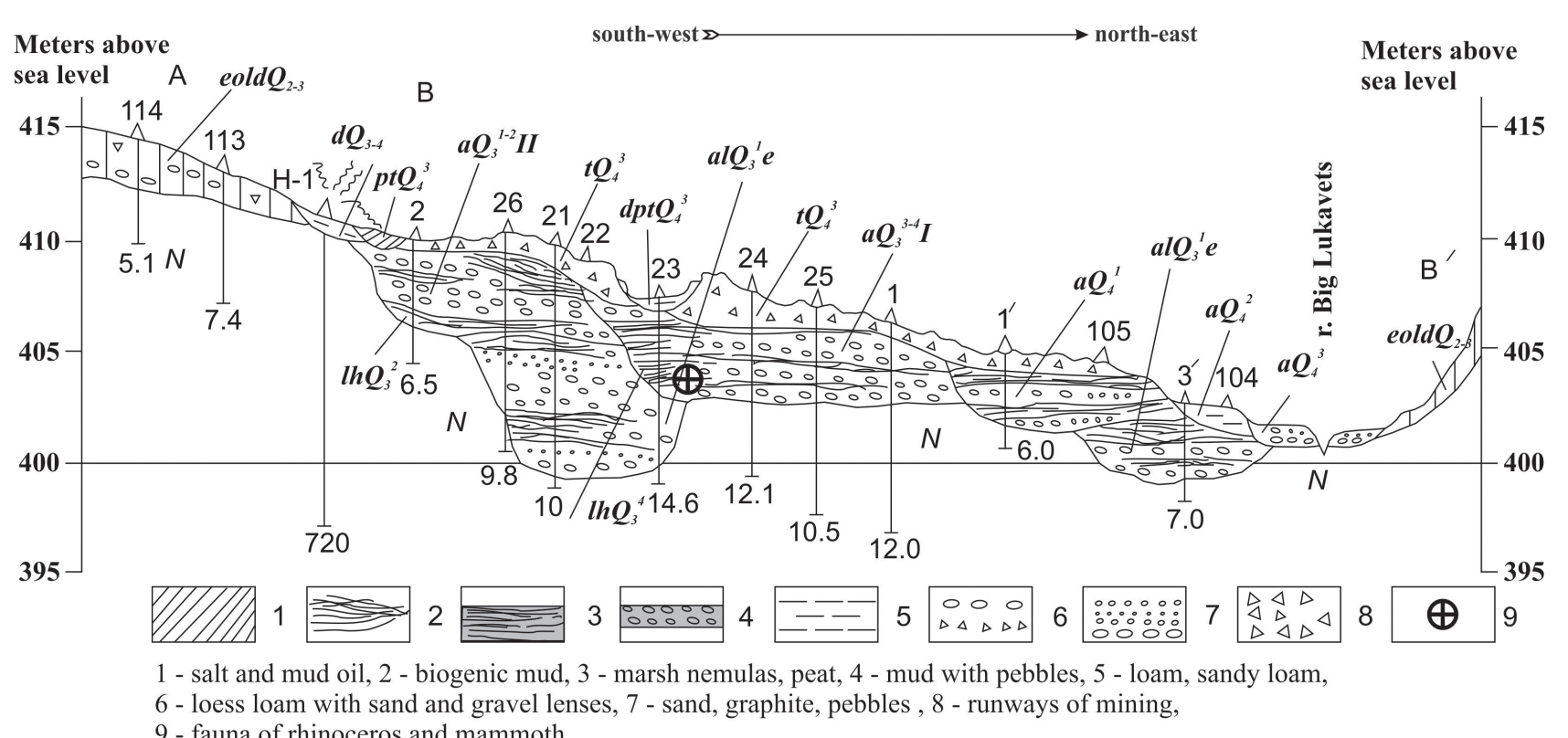

Fig. 2. Cross section (profile) of the valley of Big Lukavets rive

numerous cones (inner delta) and the ancient valley of the Dniester, located in the district of the presentday village Loeva, about 30-40 km southwest of its present position near the town of Galich.

The rise of the Carpathians gradually pushed the Dniester east-north-east. Large- alluvium deposits formed two ancient Late Pliocene terraced plains - VII (Krasnaja) and VI (Loev). The climate was subtropical, like the current Mediterranean, as evidenced by the reddish-brown colour of the sand-clay cement globular alluvium and overlying clay. Their colour is due to the active migration of hydroxides of iron.

In the early Pleistocene the $\mathrm{V}$ (Galician) terrace of the Dniester was formed, in the middle - IV (Mariyampol), and in the beginning of the late - III (Yezupil) terraces. Then the history of the Dniester continues with the Veliki Lukovets. From the beginning, in the Eemian interglacial, the redevelopment of its valley was 10-15 m deeper than the modern channel (Fig. 2) under the influence of the warm and humid climate and neotectonic activity.

The landscapes were of tundra type, with dwarf birch (Betula nana), alder (Alnus), basket willow (Salix viminalis), etc. The climate was harsh, and corresponded to the Würm glaciations (59-13 thousand years ago). Its maximum occurred 18-16 thousand years ago, when the first above-floodplain terrace had already begun to form. Perhaps it was particularly at that time when herds of wooly rhinoceroses and mammoths grazed in the valley of Starunia and the Cro-Magnons who hunted them lived. During the late pleniglacial and the late Weichselian glaciation (Bølling-Allerød-early Dryas), the first terrace continued to form. The valley of Lukovets Velyky was rejuvenated, and new stream-bed facies appeared. Tundra conditions changed to forest-steppe conditions. Thus, it continued from 13.0 to 10.2 thousand years ago, that is the early Holocene. T. Sokolowski and R. Stachowicz-Rybka (Sokolowski T., StachowiczRybka R., 2009) write that in the valley, instead of swamps, lakes appeared, which were often saline, related to thermo-karst processes. On the shore slopes of the Lukovets Velyky and the Rinne stream, shifts often occur due to the impact of solifluction.

At the border of the late Weichselian and Holocene, a division of the relief took place, but the Lukovets Velyky had lower energy compared to current epoch. Neotectonic movements and changes in climate led to formation of three levels of floodplain during the Holocene - high (Eo-Holocene), middle (Meso-Holocene) and low (Late Holocene).

Conclusions. In the future, it is planned to perform georadar sensing and other detailed geo-ecological and exploratory works at Starunia - this is a paleoclimatic benchmark survey for the development of the nature of ancient geosystems, a bridge between the stratigraphic schemes of the Quartet of Western Europe and the lowland territory of Ukraine; this is a globally unique paleontological location, famous for its well preserved mummified carcasses of woolly rhinos, this is the only active mud volcano in the Carpathians and, finally, it is an extremely interesting object of international tourism. The author has the hope that there will be investors who will help save for future generations the unique phenomenon of Starunia. 


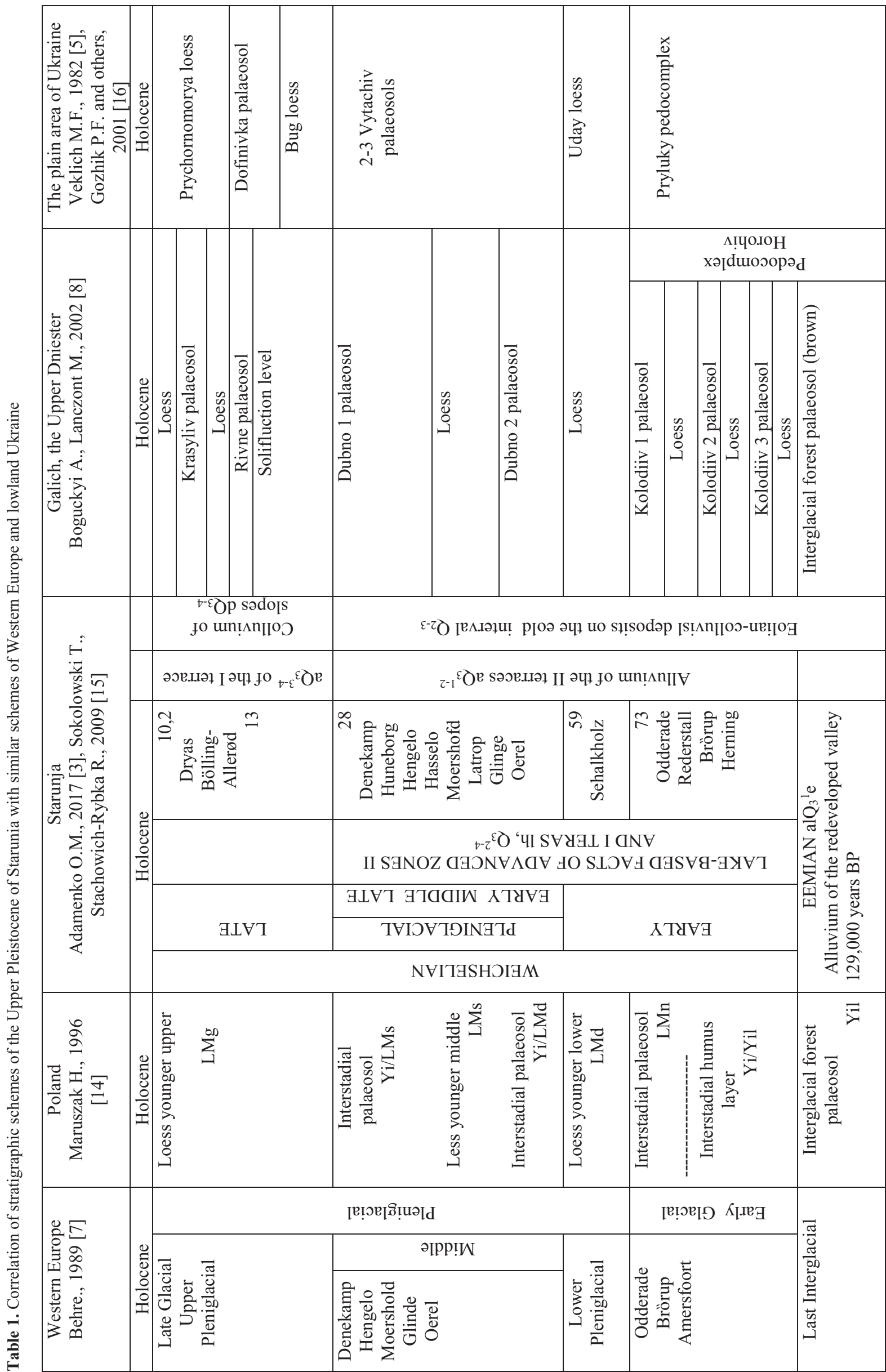




\section{References}

Adamenko O.M., Kryzhanivskyi Ye.I., V.I. Vekeryk. 2005. Vykorystannia vidpratsovanoho ozokerytovoho rodovyshcha dlia stvorennia ekolohoturystychnoho tsentru u s. Starunia na Prykarpatti. [Use of a worked out ozokerite deposit for the creation of an ecological and tourist center in the village of Starunya in the Carpathian region]. Exploration and development of oil and gas deposits. 1(14), 122 - 129 (in Ukrainian).

Adamenko O.M. 2007. Nash maibutnii dim - Ekoievropa. [Our future home is Ecoeurope]. Novel life, science and love in 4 volumes - Volume Four]. Ivano-Frankivsk: Symphony forte, 428 p. (in Ukrainian).

Adamenko O.M.. Karpash O.M., Zorin D.O., Kotarba, I.V., Mosiuk, I.I. Kovbaniuk M.I., 2017. [Starunya: Park of the Ice Age]. Ivano-Frankivsk: Symfoniia forte, 214 p. (in Ukrainian).

Belous N. Kh., Kliarovskyi V.M. 1987. Chudo-Starunia (Heolohycheskye pamiatnyky Ukraynu). [Miracle of Starunya (Geological Monuments of Ukraine). Kyiv, Naukova dumka, 48-49 (in Ukrainian).

Veklych M.F. 1982. Paleoetapnost y stratotypy pochvennyh formacyj verhnego kajnozoja. [Paleo stages and stratotypes of soil formations of the upper Cenozoic]. 201, - Kyev, Nauk.dumka, (in Russian).

Bayger J.A., 1914. Zaba smieszka: in: Bayger J.A Hover H., Kiernik E., Kulczynski W., Lomnicki M., Lomnicki J., Mierzejewski W., Niezabitowski W., Raciborski M., Szafer W., Schille F. Wykopaliska Starunskie. Muzeum im. Dzieduszyckich we Lwow, 15: 385.

Behre K.E., 1989. Biostratigraphy of the last glacial period in Europe. Quarternary Science Reviews, 8: 2544.

Boguckyi, A., Lanczont, M., 2002. Stratigrafia lessow Naddnisterza halickiego. Studclia Geologia Polonica, vol. 119, Krakow: 315-329.

Kotarba M.J., 2005. Polish and Ukrainian geological studies (2004-2005) at Starunia - the area of discoveries of woolly rhinoceroses. Polish Geological Institute and Society of Research on Environmental Changes "Geosphere". Warszawa, Krakow: $9-218$.

Kotarba, M.J., 2009. Interdisciplinary Studies (2006-2009) at Starunia (Carpathian Region Ukraine) - the area of discoveries of discoveries of Woolly Rhinoceroses. Annales Societatis Geologorum Poloniae, vol. 79, 3. Krakow, 217-480.

Kuc, T., Rozahski K., Goslar T., Stachowicz - Rybka R., 2009. Radiocarbon dating of plant remnants in Quaternary sediments at Starunia paleontological site and vicinity (Carpathian region, Ukraine). Annales Soeietatis Geologorum Poloniae, 79: 289-296.

Lomnicki M., 1908. - Discovery of mammoth (Elephas primigenius Blumb.) and diluvial rhinoceros (Rhinocoeros antiquitatis Blumb.) in Starunia (pow. Bohorodczanski). Kosmos, 33: 63-70.

Matskevyj L.G., 2005 Archaeological sites in the Starunia area, fore- Carpathian region, Ukraine. - Polish and Ukrainian geological studies (2004-2005) at Starunia - the area of discoveries of woolly rhinoceroses. - Warszawa-Krakow: 45- 51.

Maruczak H., 1996. Korelacia stratygraphiczna polskich, ukrainskich I niemieckich (Stratigraphyc correlation of Polish, Ukranian and German loesses). Biuletyn Panstwowego Instytutu Geologicznego, 373:107-115.

Sokolowski T., Stachowicz-Rybka R., 2009. Chronostratigraphy and changes of environment of Late Pleistocene and Holocene at Starunia palaeontological site and vicinity (Carpathian region, Ukraine). Annales Societatis Geologorum Poloniae, 79: 315-331.

Gozhik P., Matviishina Zh., Rekovets L, Shelkoplyas V., 2001. Quaternary stratigraphy. INQUA SEQS, Subcommision on European Quaternary stratigraphy, The Ukraine Quaternary Expored: the Middle Dnieper Area and its importance of East-West correlation. Kyiv, Excursion quide: 3-62. 